\title{
Ökotoxikológiai vizsgálatok televényférgekkel (Annelida: Enchytraeidae)
}

A televényférgek biológiájáról sokáig igen keveset tudtunk, annak ellenére, hogy a talajban található szerves anyagok lebontásában hasonlóan fontos a szerepük, mint a földigilisztáknak (DIDDEN, 1993). A rendelkezésre álló tapasztalatok összegyüjtésével felismerték, hogy ezek az élölények, összehasonlítva más talajlakó állatcsoportokkal, meglehetősen érzékenyen reagálnak a vegyi anyagokra (BECK et al., 1988; RozEN et al., 2004). Ma már tudjuk, hogy a peszticidek közvetlenül (pl. gombaölők) és közvetett (pl. gyomirtók, a tápanyagkészlet csökkentésén keresztül) módon is képesek kedvezőtlen hatást kifejteni a televényférgekre (DIDDEN \& RöMBKE, 2001). Mindezeken túl, számos adat került birtokunkba a különböző nehézfémek és mikroelemek televényférgekre gyakorolt hatásairól is (DIDDEN \& RÖMBKE, 2001; LOCK \& JANSSEN, 2001a,b, 2002a,b).

A televényférgek ökotoxikológiai tesztekben való első felhasználása és ennek publikálása közel negyven évvel ezelőtt történt (WEUFFEN, 1968). Az első szabványosított eljárások néhány televényféreg fajra (Enchytraeus albidus, Enchytraeus crypticus) több mint 20 évvel ezelőtt születtek, de csak RÖMBKE és MOSER (2002) munkája nyomán váltak általánosan ismertté. Az eljárások fejlődése nyomán, ezeket az állatokat nem csak talajon, hanem vízben (RÖMBKE \& KNACKER, 1989; ACHAZI et al., 1995) és agaron (ESSER \& OVERDIECK, 1991; ARRATE et al., 2002) is alkalmazták.

A különböző tesztek eredményei között nagy eltéréseket figyeltek meg. A tesztek egymással való jobb összehasonlíthatósága miatt RÖMBKE és MOSER (1999) dolgoztak ki egy tesztmódszert, mely mind a mai napig a televényférgekkel végzett laboratóriumi ökotoxikológai vizsgálatok alapját képezi.

\section{A televényférgek biológiája}

A televényférgek a gyürüsférgek (Annelida) törzsébe, a nyeregképzők (Clitellata) osztályába, a kevéssertéjü gyürüsférgek (Oligochaeta) alosztályába tartoznak (DózSAFARKAS 2002). Közép-Európában a televényféreg fajok száma valószínűleg 200-300 között van. Ezek körülbelül 20 nembe sorolhatók. Sok fajnál és nemnél azonban égetően szükséges a felülvizsgálat. Ezeket gyakran igen csekély morfológiai különbségek alapján minősítették önálló fajjá NIELSEN és CHRISTENSEN (1959) monográfiája szerint. Valószínűleg azonban ezek a taxonómiai problémák (WESTHEIDE \& SCHMELZ, 1997) a biokémiai és a genetikai módszerek elterjedésével oldódhatnak meg. 
Leggyakrabban fehér vagy fehéres színüek, mivel a fajok zöménél nem találunk pigmentet a kültakaróban. Ritkán, ha testfolyadékuk színanyagokat is tartalmaz sárgás, rózsaszínes vagy éppen zöldes színt vehetnek fel. Testhosszúságuk 1,5-45 mm, testszélességük általában 0,09-1,20 mm között ingadozik. A szelvények száma a kifejlett (adult) állatoknál 18 és 90 között változik. A kisebb fajok átlagosan 25-30, a közepes, ill. nagy testű fajok 35-60 szelvénnyel rendelkeznek. A frissen kelt (juvenil) állatoknak kb. 10 szelvényük van. A serték kötegekbe, sertecsomókba rendeződve találhatók az állatokon. Általában négy köteg szelvényenként. Kettő helyezkedik el hasirányba (ventrálisan), kettő pedig oldalsó (laterális) irányba. Az oldalsó (laterális) csomókat gyakran nevezik háti (dorsalis) sertéknek. Többnyire hímnősek, ivarosan szaporodnak, de kisebb részben képesek fragmentálódni. Az egyedfejlődés sebessége több tényező mellett elsősorban a hőmérséklettől függ: tarthat akár néhány héttől fél évig is. Laboratóriumban akár 300 napig is élhetnek (CHALUPSKÝ, 1991; DÓZSA-FARKAS 2002). Emberi behatásoktól mentes területeken, a négyzetméterenkénti átlagos televényféreg szám 20 ezer és 60 ezer közötti. Átlagos biomasszájuk 0,4-1,2 g száraz tömeg/m². Savanyú talajon ezek a számok gyakran magasabbak, mint semleges $\mathrm{pH}$ mellett. Az Enchytraeus albidus számára az optimális talajkémhatás $\mathrm{pH}=6$ (KURT, 1961). Több tényező, közöttük a talaj szervesanyag- és nedvességtartalma befolyásolja előfordulásukat és reakciójukat az őket érő stresszfaktorokra (JÄNSCH \& RÖMBKE, 2003).

Életmódbeli hasonlóságuk lehetővé tenné és lényegesen kisebb számban ugyan, de találunk más, pl. Cognettia fajokkal elvégzett toxikológiai vizsgálatokat (SALMINEN et al., 1996; SALMINEN \& SulKAVA, 1997), mégis csak az Enchytraeus nembe tartozó fajokkal végeznek standardizált ökotoxikológiai laboratóriumi teszteket. Ezek a fajok jellemzően emberi zavarásnak kitett helyeken élnek (pl. utak mentén), könnyen tenyészthetők és kereskedelmi célú felhasználásuk is ismert, mint haleleség. A közönséges televényféreg (Enchytraeus albidus), kétséget kizáróan elkülöníthető a többi Enchytraeus fajtól, jellegzetes belső szervei alapján (KASPRZAK, 1986; NIELSEN \& CHRISTENSEN, 1959). Ökológiai igényei aránylag jól ismertek (IVLEVA, 1953a,b,c, 1960; KURT, 1961). Gyors az egyedfejlődésük, különböző anyagokon (természetes talaj, OECD talaj, agar) tarthatók, változatosan etethetők és mindhárom vizsgálati szinten (laboratórium, félszabadföldi, szabadföldi) alkalmazhatók (RÖMBKE et al., 1994). Számos kisebb Enchytraeus faj, (E. crypticus, E. buchholzi, E. luxuriosus és E. bulbosus) ezzel ellentétben gyakran keveredhetnek és egy fajhibridekből álló populációt, az $E$. buchholzi-komplexet hoznak létre, ezért a toxikológiai tesztekben való alkalmazásuk nagyfokú körültekintést igényel.

\section{Enchytraeus Reprodukciós Teszt (ERT)}

RÖMBKE és MOSER (1999) kifejlesztett egy krónikus, laboratóriumi tesztet, melynek tervezésénél figyelembe vették a földigiliszták és az ugróvillások hasonló tesztjeit (ISO 1998, 1999). Ezt a tesztet sokáig elsősorban egy-egy anyag hatásának tesztelésére alkalmazták. Az eredetileg kidolgozott módszer módosításával az elmúlt néhány évben, elsősorban Németországban, gyakran alkalmazzák a televényférgeket a talajok minősítésére, a talajok minőségének vizsgálatára (RÖMBKE et al., 2000, HUND-RINKE et al., 2002a,b). Pótlólag a teszt időtartamát, a tesztedények méretét, a szükséges vizsgálati anyag és a táplálék mennyiségét, valamint az érvényességi kritériumokat (szaporulat 
száma) változtatták meg. E változtatások azért történtek, hogy a teszt alkalmas legyen természetben szennyeződött talajok vizsgálatára is. A jelenleg használatos módszer a kifejlett (adult) állatoknál az életben maradási és a szaporodási képességet vizsgálja. A tesztállat a közönséges televényféreg (Enchytraeus albidus), esetleg más faj, a génuszon belül, ha az egyértelmüen azonosítható és tömegesen tenyészthető. A tesztek időtartama elővizsgálatok esetében 2 hét, a fő teszt a kísérleti állattól függően, Enchytraeus albidus esetében 6 hét, más fajok esetében 4 hét. A vizsgálat történhet mesterséges talajon: kvarc homok, kaolin, tőzeg, kalcium-karbonát és víz OECD (1984) szabványa által meghatározott keverékén vagy természetes talajon. Ennek megfelelően a vizsgált anyag tesztelése kétféle módon történhet. Egyrészt hozzákeverve a mesterséges talajhoz, másrészt a természetben szennyeződött, ill. szennyeződésmentes (kontroll) talaj összehasonlító vizsgálatával. A kísérlet beállításához 10 kifejlett (nyereggel rendelkező) állatot helyezünk a tesztedényekbe (zárható, 0,2-0,25 1 térfogatú). Az edényeket, fénymentesen, temperált hömérséklet $\left(20 \pm 2{ }^{\circ} \mathrm{C}\right)$ és $40-60 \%$ páratartalom mellett tartjuk és hetente egyszer örölt zabpehellyel etetjük az állatokat. A teszt érvényességének feltétele, hogy a kontrolledényekben a kifejlett állatok mortalitása kisebb legyen 20\%-nál, az utódok száma pedig, Enchytraeus albidus esetében 25-nél, más tesztállat esetében 50-nél legyen több egy edényben a kísérlet végén. A teszt kiértékelésekor NOEC (no observed effect concentration - a legmagasabb, vizsgált, statisztikailag kimutatható hatással még nem rendelkezö koncentráció) és ECx (effect concentration - a vizsgált, mint $\mathrm{x} \%$-ra ható koncentráció) értéket határoznak meg. Referenciaanyagként Carbendazim 1,2 $\pm 0,8$ $\mathrm{mg} / \mathrm{kg}$ koncentrációját használják.

\section{A módszer kipróbálása}

A Német Szövetségi Környezetvédelmi Ügynökség (UBA, Berlin) megbízásából, az Európai Vegyészeti Hivatal (ECB, Ispra) segítségével próbálták ki az ERT-t egy nemzetközi körvizsgálatban (RÖMBKE \& MOSER, 1999, 2002). 15 országból, összesen 29 akadémiai és magán laboratórium vett részt a munkában. A legtöbb résztvevő négy kísérletet végezett, két vegyszerrel (Carbendazim és 4-Nitrofenol), két ismétlésben, a NOEC és az ECx tesztekre vonatkozó elöírásoknak megfelelően. A statisztikai kiértékeléseket követően váltak összehasonlíthatóvá a kapott értékek. Mindeddig összesen több mint 20 kémiai anyagot vizsgáltak az új módszer segítségével, beleértve a kidolgozás folyamatát is. Az egyes kémiai anyagok hatását vizsgáló ERT eredményeket közlő cikkek a következők: réz, cink (PostuMA et al., 1997); Dimetoát (PUURTINEN \& MARTIKAINEN, 1997 - RÖMBKE, 2003 nyomán); Carbendazim, 4-Nitrofenol (COLLADO et al., 1999; RÖMBKE \& MOSER, 2002); Lindán (AMORIM et al., 1999; LOCK et al., 2002); Malation (KUPERMAN et al., 1999); TNT, katonai szennyezők (SCHÄFER \& ACHAZI, 1999); Tylosin, Oxitetraciklin (BAGUER et al., 2000); cink (PosthuMA \& NotenboOM, 2000; BeYlich, 2001); PAH vegyületek (Svedrup et al., 2002 RÖMBKE, 2003 nyomán); As, Cd, Cu, Ni, Pb, Zn (LOCK, 2002); TNT (DODARD et al., 2003). Majd minden tesztben az eredményként kapott $\mathrm{EC}_{10}$ értékek alacsonyabbak voltak, mint a megfelelő számított NOEC-értékek (1. ábra). Ezek alapján vonható le az a következtetés, hogy az ECx-értékek vizsgálata pontosabban használható a kémiai anyagok okozta kockázat felmérésére (WEYERS et al. 2002). Figyelembe véve, hogy a hatóságok számára a környezeti kockázatok felbecsülése a legfontosabb, az eddig megkövetelt NOEC-értékek helyett, kombináltan NOEC- és az ECX-értékek együttes közlése 


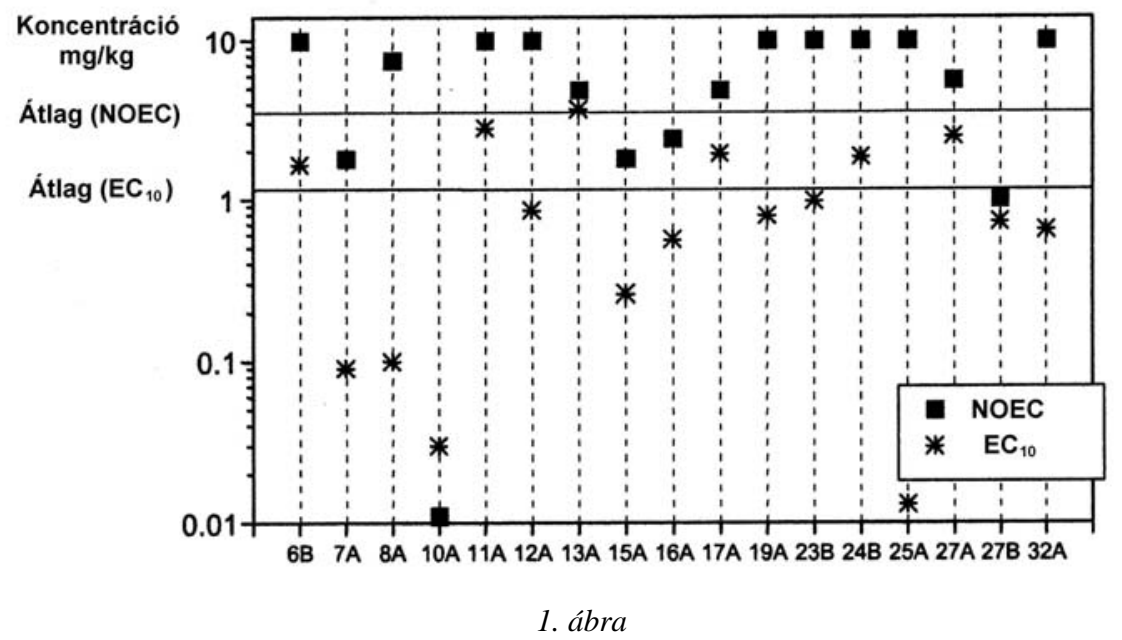

Egyedi NOEC- és $E_{10}$-értékek az összes érvényes ERT ring tesztben, Carbendazimra (WeYERS et al., 2002). Megjegyzés: A vízszintes tengelyen a vizsgálatban részt vevő és értékelhető eredményt kapó laboratóriumok kódjai találhatóak

javasolt. Jelenleg az ERT-ből kifejlesztett következő szabványok vannak érvényben: ASTM E 1676-97 (2000), ISO 16387 (2002) és az OECD 220 (2003).

Természetesen az ERT-t felhasználva egyéb, a szabványban meg nem határozott paraméterek tanulmányozására is lehetőség van. Ilyen lehet a kifejlett és fiatal egyedek érzékenység-különbségének, vagy a különböző szennyezők biotranszformációjának a vizsgálata. Ezt bizonyítja DODARD és munkatársai (2003) munkája, akik a 2,4,6-Trinitrotoluol (TNT) 21 és 42 napos hatását vizsgálták a kifejlett és a fiatal egyedekre. Kísérleteik végén megállapították, hogy a kijutatott szennyező anyag 5-10-szer erősebben fejti ki hatását a fiatal állatokra, mint a felnőttekre. Nyilvánvalóvá vált az is, hogy ez a hatás az első 21 napban lényegesen erősebb, mint a kísérlet második felében. A korszerinti érzékenység tekintetében hasonló eredményeket kaptak SOMOGYI és munkatársai (2004) hat nehézfém és a szelén hatását tanulmányozva, 42 napos kísérletben. Megállapítható volt, hogy a fiatal egyedek 2-3-szor kisebb mennyiségben kijuttatott szennyezőre is érzékenyebben reagáltak, mint a kifejlett állatok. A tesztmódszer alapjainak felhasználásával egészen más szempontot vizsgáltak DODARD és munkatársai (2004), akik arra keresték a választ, hogy más alacsonyabb rendü élölényekhez hasonlóan, a közönséges televényférgek képesek-e a 2,4,6-Trinitrotoluol (TNT) szennyezők biotranszformációjára. Kísérleteiket a korábbi munkájuk alapján megállapított, még nem letális koncentrációk mellett végezték. Véleményük szerint mind mesterséges, mind természetes körülmények között képesek az állatok a TNT bizonyos mértékü biotranszformációjára. Az eddig elvégzett vizsgálatokból még nem derült ki, hogy a biotranszformációt az állatok, esetleg a bélcsatornájukban élö baktériumok végezték-e el.

A televényférgekkel végzett talajtoxikológiai tesztek kezdetén kételyek merültek fel az állatcsoport alkalmazhatóságát illetően. Néhányan kétségbe vonták, hogy a földigiliszták és az ugróvillások mellett van-e létjogosultsága ennek az újabb fajnak. A kéte- 
lyek eloszlatása, valamint a televényférgek alkalmasságának bizonyítása végett napjainkig több kísérletet végeztek. Különböző kémiai anyagok (Carbendazim, Lindán, LAS, Dimetoát) és nehézfémek ( $\mathrm{Zn}, \mathrm{Cd}, \mathrm{Mn})$ esetében vizsgálták e három állatcsoport, toxikus anyagokra mutatott reakcióját, valamint az okozott hatások különbségét (MARTIKAINEN, 1996; JENSEN et al., 2001; LOCK, 2002; LOCK et al., 2002; RÖMBKE \& MOSER, 2002; KUPERMAN et al., 2004). A vizsgálatokban a következő állatokat alkalmazták: földigiliszták (Eisenia fetida, Apor-rectodea caliginosa tuberculata), ugróvillások (Folsomia candida) és televényférgek (Enchytraeus albidus, Enchytraeus crypticus). Ezek alapján cáfolható CAIRNS (1986) kijelentése, mely szerint ez a faj, kis érzékenysége miatt nem lenne alkalmas ökotoxikológiai tesztekre. A kísérletek kimutatták, hogy a televényférgek legalább annyira érzékenyek az antropogén stresszfaktorokra, mint más talajlakó gerinctelenek.

\section{A talajminőség értékelése}

Az ERT-t még a szabványosítások folyamata alatt módosításra került (ISO 16387 B 2002) a felmerülő új igényeknek megfelelően. Az eredetileg kiinduló faj a közönséges televényféreg (Enchytraeus albidus) mellett új fajként az Enchytraeus crypticus-t ajánlották, mivel ökológiai szükségleteit nagyjából ismerték (ACHAZI et al., 1999; FILIMONOVA \& POKARZHEVSKII, 2000). A kísérletek folyamán különböző anyagokkal szennyezett talajokat teszteltek. A vizsgálatokat elsősorban Németországban, Hollandiában és Oroszországban végeztek. A talajminőség vizsgálatára különböző szennyező anyagokkal végzett ERT eredményeket közlő cikkek 1996 és 2002 között a következők voltak: PAH vegyületek, nehézfémek (ACHAZI et al., 1996; HUND-RINKE et al., 2002b); TNT (SCHÄFER \& ACHAZI, 1999 - RÖMBKE, 2003 nyomán); nyers olaj, PAH vegyületek (FILIMONOVA \& POKARZHEVSKII, 2000); olajszennyezés, PAH vegyületek (Juvonen et al., 2000); Cd, Zn (PosthumA \& NotenBoOM, 2000; RöMBKE et al., 2002). A tesztelésben mindössze öt laboratórium vett részt. Ezek közül is csak kettő rendelkezett már valamilyen tapasztalattal a televényférgekkel kapcsolatban, a tesztek megindulása előtt. A szennyező anyagok TNT, ásványi olaj, nehézfémek és PAH vegyületek voltak. A tesztállat az Enchytraeus cryp-ticus volt, kontrollként pedig a LUFA 2.2 (BEYLICH, 2001) standard talajt használták. A legérdekesebb eredmények a hollandiai Budelban születtek (PosTHUMA \& NOTEN-BOOM, 2000; RÖMBKE et al., 2002). Itt nehézfémekkel, elsősorban cinkkel és kadmiummal szennyezett talajokat vizsgáltak, remediáció előtt és után. A különböző remediációs eljárások hatására, a szennyezőanyag-koncentráció minden esetben kimutathatóan és értékelhetően csökkent. Tesztállatnak az Enchytraeus crypticus-t választották és a LUFA 2.2 standard talajt használtak kontrollnak. Ezt hozzákeverték a vizsgált talajhoz, amivel a két talaj alaptulajdonságait tekintve hasonlóvá vált. A remediáció után csak a talajok 50\%-ánál lett alacsonyabb a toxicitási szint, a televényférgekre, mint a remediációt megelőzően. A kapott eredményekböl látható, hogy ezek a biológiai tesztek, nemcsak a szennyező anyagok okozta hatást mutatták ki, hanem valamilyen más, eddig ismeretlen faktort is, amely hatással van a talajok minőségére, valamint a talajban található szennyezők tesztállatra gyakorolt hatására. 


\section{Kidolgozás alatt álló módszerek}

\section{Magatartás tesztek}

A földigiliszták elkerüléses tesztjeinek (YEARDLEY et al., 1996; SLIMAK, 1997) tapasztalataiból kiindulva ACHAZI és munkatársai $(1996 ; 1999)$ tettek javaslatot egy hasonló teszt létrehozására, televényférgekkel. A 48 órás időtartamú teszt lényege, hogy meghatározza a televényférgek talajválasztását. Vizsgálják a tesztállat mozgását, és hogy mely területet népesítik be jobban a teszt végére. A tesztállat az Enchytraeus crypticus, Enchytraeus albidus vagy más Enchytraeidae családba tartozó faj, amely
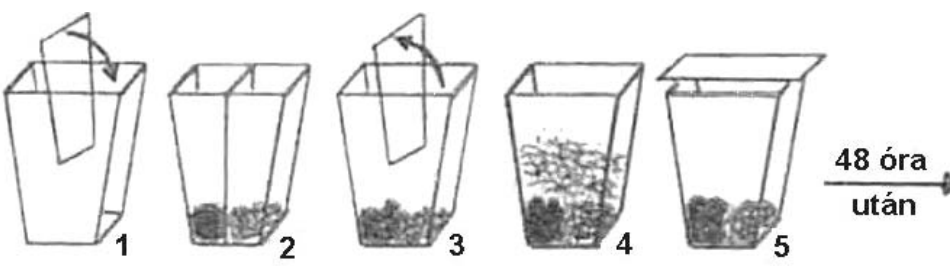

2. ábra

Sematikus vázlat a televényférgek (Enchytraeidae) elkerüléses teszt kísérleti eljárásáról (AMORIM et al., 2005 nyomán). 1. A mozgatható válaszfalat behelyezzük a tesztedény közepébe. 2. A fal két oldalára helyezzük a tesztelni kívánt talajokat. 3. Eltávolítjuk a válaszfalat. 4. A televényférgeket kihelyezzük, középre a tesztedénybe. 5. Letakarjuk a tesztedényt. 6. Visszahelyezzük a falat, szeparáljuk a két talajt egymástól és azonnal megszámoljuk a két oldalon található állatokat

laboratóriumi tömegtenyészetben fenntartható. A vizsgált anyagot hozzá lehet keverni mesterséges talajhoz, de alkalmazható szennyezett természetes talaj és kontrolltalaj keveréke is. A kontrolltalaj minden esetben LUFA 2.2 standardizált talaj. Egy-egy tesztedénybe 20 kifejlett állatot helyezünk, $20 \mathrm{~g}$ talajra (10 g kontroll- és $10 \mathrm{~g}$ teszttalaj) (2. ábra). A hőmérséklet $20 \pm 1{ }^{\circ} \mathrm{C}$, a talajnedvesség $50 \% \mathrm{Vk}_{\max }$. Tíz ismétlést állítunk be, fénymentes környezetben. A teszt akkor érvényes, ha az elhullás nem több mint $20 \%$. A teszt kiértékelésekor a tesztedényekben tapasztalható különböző eloszlást vetjük össze a kontrolltalajban tapasztalható eloszlással. Elkerülést vizsgálva, a 20 állatot a kontrolltalajra helyezzük, menekülést vizsgálva pedig a teszttalajra. Kombinált teszt esetében a 20 állatot egy vonalban teszünk ki a két oldal közé, vagy 10-10 állatot mindkét oldalra (ACHAZI et al., 1999).

Magatartás teszteket végeztek nehézfémekkel (RöMBKE, 2003) és különböző növényvédő szerekkel: gombaölő szer (Benomyl - Solo de DuPont, 50\%; Carbendazim AgrEvo, 360 g/l), gyomirtó szer (Phenmedipham - Stähler Agrochemie, $157 \mathrm{~g} / \mathrm{l}$ ) (AMORIM et al., 2005) és rovarölő szer (Cymbusch) (RÖMBKE, 2003). Az ólommal szemben meneküléses reakciót tapasztaltak, míg a kadmiumot nem érzékelte a kijutatott koncentrációkban a tesztállat. A különböző peszticidek közül a Cymbusch rovarölő szer váltott ki menekülést, már nagyon alacsony $(0,04 \mathrm{mg} / \mathrm{kg})$ koncentrációban (RöMBKE 2003). A többi növényvédő szer esetében megfigyelhető volt, hogy a hatást nagyon erősen befolyásolta, hogy milyen talajon végezték a kísérletet. AMORIM és munkatársai (2005) kétféle mesterséges talajt (OECD, 1984; LUFA 2.2) és több, Ausztriából, Görög- 
országból és Németországból származó természetes talajt teszteltek. Általánosságban elmondható, hogy a LUFA 2.2 talajon minden esetben hamarabb jelentkezett a menekülés, mint az OECD (1984) talajon, míg a természetes talajokon ez még inkább felerösödött, de a Cymbusch rovarölő szerhez hasonló alacsony koncentrációnál egyik esetben sem találtak kimutatható reakciót.

Ezek a magatartás tesztek hasznos kiegészítői lehetnek a már létező akut és krónikus teszteknek, mivel a talajról vagy a vizsgált anyag toxikusságáról már a 48 órás teszt lezárását követően, néhány napon belül megkaphatjuk az első eredményeket. Jelenleg a földigilisztákra már elfogadtak egy ISO szabvány tervezetet (ISO, 2004), míg a televényférgekre kidolgozott módszer szabványosítása folyamatban van.

\section{Bioakkumulációs tesztek}

A Német Szövetségi Környezetvédelmi Ügynökség (UBA, Berlin) 4 évvel ezelőtt pénzalapot hozott létre egy szabványosított eljárás kidolgozására, mellyel a vegyi anyagok bioakkumulációjának mértékét meg tudják határozni a földigilisztáknál és a televényférgeknél (BRUNS et al., 2001). A rovarölő szerek közül a Lindánt, míg a gombaölő szerek közül a hexaklór-benzolt alkalmazták, mint modellvegyszert. Két televényféreg fajt (E. albidus, E. luxuriosus) választottak ki tesztállatnak, könnyü kezelhetőségük és a talajban betöltött fontos ökológiai szerepük miatt. Mesterséges és természetes talajokat is alkalmaztak a vizsgálatokhoz. A tesztben szereplő koncentrációkat, a korábban a különbözö fajokon elvégzett akut és reprodukciós toxicitási vizsgálatok eredményei alapján határozták meg. A teszt idejét 42 napban határozták meg. Az eredmények alapján látható, hogy mind a két vegyszer lényegesen nagyobb mértékben akkumulálódott a két televényféreg fajban, mint a földigilisztákban. A bioakkumulációs faktor (BAFs) mindkét vegyszerre nézve szignifikánsan magasabb volt a televényférgekben. Az eddigi adatok arra utalnak, hogy a két televényféreg közül a kisebbik (E. luxuriosus) valamivel jobban akkumulálja a két vegyszert, mint az E. albidus. A mesterséges talajon az is látható, hogy a kémiai anyagok a tesztek egy jelentékeny százalékában szinte teljesen eliminálódtak a talajból. Hasonló tapasztalatokról számolt be egy portugál kutatócsoport is (AMORIM et al., 2002), akik ugyancsak a Lindánt vizsgálták mesterséges és természetes talajon is. Megállapították, hogy a mesterséges talajra kijutatott Lindán $90 \%$-a két nappal a kiadást követöen eliminálódott. Ugyanez az érték a természetes talaj esetében $67 \%$ volt. Ennek megfelelően a mesterséges talajon számolt bioakkumulációs faktor 6 körüli értéket mutatott, míg természetes talajon 10 körüli értéket számoltak. Hasonló jellegủ kísérleteket végzett nehézfémek felhasználásával LOCK és JANSSEN (2001c).

\section{Összefoglalás}

Az Enchytraeidae (Oligochaeta, Annelida) családba tartozó kistestű televényférgek, fontos szerepet töltenek be sok ökoszisztémában. Rendkívül érzékenyek az antropogén stresszfaktorokra, mégis sokáig elhanyagolták őket, mint tesztállatokat. Az Enchytraeus Reprodukciós Teszt (ERT) különböző kémiai anyagok hatásvizsgálatára, valamint talajminőség megállapításához fejlesztették ki. A kidolgozott új módszer révén lehetőség nyílt a korábbi, különböző tesztek eredményeiben megfigyelhető nagy változatosság csökkentésére, valamint tanulmányozhatóvá vált a televényférgek különböző antropo- 
gén stresszfaktorokkal szemben mutatott érzékenysége. Az ERT alapján dolgoztak ki és fogadtak el több szabványosított teszteljárást (ASTM E 1676-97; ISO 16387; OECD 220). Mindezek mellett folyamatban van új eljárások kidolgozása is, melyek egyrészt a televényférgek magatartás vizsgálatán, másrészt a bioakkumulációs hatásokon alapulnak.

A számos különböző kísérlet, a már elfogadott és a még folyamatban lévő nemzetközi szabványok mind-mind megerősítik, hogy ez az állatcsoport (Enchytraeidae) és ezen belül is alapvetően három faj (E. albidus, E. crypticus és E. luxuriosus) különösen alkalmas talajokon végzett ökotoxikológiai tesztekre.

\section{Irodalom}

ACHAZI, R. K. et al., 1995. Einfluss von anthropogenen Schadstoffen auf terrestrische Invertebraten: 2. Einfluss von BaP, Fla und $\mathrm{Cd}$ auf Lebensciklus parameter von Enchytraeus crypticus in Labor-testsystemen. Verhandlungen der Gesellschaft für Ökologie. 24. 535-540.

ACHAZI, R. K. et al., 1996. Der Einfluss des pH-Werts und von PCB52 auf reproduktion und Besiedlungsaktivität von terrestrischen Enchytraeen in PAK-, PCB- und schwermetallbelasteten Riesefeldböden. Verhandlungen der Gesellschaft für Ökologie. 26. 37-42.

ACHAZI, R. K. et al., 1999. The effect of soil from former irrigation fields and of sewage sludge on dispersal activity and colonizing success of the annelid Enchytraeus crypticus (Enchytraeidae, Oligochaeta). Newsletter on Enchytraeidae. 6. 117-126.

Amorim, M. J. B., RÖmbKe, J. \& SOARes, A. M. V. M., 2005. Avoidance behaviour of Enchytraeus albidus: Effects of Benomyl, Carbendazim, Phenmedipham and different soil types. Chemosphere. 59. 501-510.

AmoRim, M. J. B. et al., 1999. Comparison of chronic toxicity of Lindane $(\gamma-\mathrm{HCH})$ to Enchytraeus albidus in two soil types: the influence of soil pH. Pedobiologia. 43. 635-640.

Amorim, M. J. B. et al., 2002. Bioavailability and toxiokinetics of ${ }^{14} \mathrm{C}$-Lindane (gamma-HCH) in the Enchytraeid (Enchytraeus albidus) in two soil types: The aging effect. Arch. Environ. Cotam. and Tox. 43. 221-228.

Arrate J. A., Rodriguez, P. \& MArtinez-MAdrid, M., 2002. Effects of three chemicals on the survival and reproduction of the oligochaete worm Enchytraeus coronatus in chronic toxicity tests. Pedobiologia. 46. 136-149.

ASTM (American Society for Testing and Materials), 2000. Standard Guide for Conducting Laboratory Soil Toxicity or Bioaccumulation Tests with the Lumbricid Earthworm Eisenia fetida and the Enchytraeid Potworm Enchytraeus albidus. ASTM Guideline No. E 1676-97.

Baguer, A. J., Jensen J. \& Krogh, P. H., 2000. Effects of the antibiotics oxytetracycline and tylosin on soil fauna. Chemosphere. 40. 751-757.

BECK, L. et al., 1988. Vergleichende ökologische Untersuchungen in einem Buchenwald nach Einwirkung von Umweltchemikalien. Jülich Special. 439. 548-701.

BEYLICH, A., 2001 Untersuchungen an Enchytraeiden (Oligochaeta) zum Einfluss von Bodenfeuchte und $\mathrm{pH}-$ Wert auf die Toxizität von Schwermetallen im Freiland und in Laborversuchen. Dissertation. Free University. Berlin.

BRUNS, E. et al., 2001. Bioaccumulation of lindane and hexachlorobenzene by the oligochaetes Enchytraeus luxuriosus and Enchytraeus albidus (Enchytraeidae, Oligochaeta, Annelida). Hydrobiologia. 463. 185-197.

CAIRNS, J., 1986. The myth of the most sensitive species. Bioscience. 36. 670-672.

ChalupskÝ, J., 1991. Comprehensive Guide to the Enchytraeidae Taxonomy. The Swedish University of Agricultural Sciences. Uppsala.

DidDEn, W. A. M., 1993. Ecology of terrestrial Enchytraeidae. Pedobiologia. 37. 2-29. 
DidDEN, W. A. M. \& RömbKe, J., 2001. Enchytraeids as organisms for chemical stress in terrestrial ecosystems. Ecotox. Environ. Saf. 50. 25-43.

Dodard, S. G., Powlowski, J. \& Sunahara, G. I., 2004. Biotransformation of 2,4,6-trinitrotoluene (TNT) by enchytraeids (Enchytraeus albidus) in vivo and in vitro. Environ. Poll. 131. $263-273$.

DODARD, S. G. et al., 2003. Lethal and subchronic effects of 2,4,6-trinitrotoluene (TNT) on Enchytraeus albidus in spiked artificial soil. Ecotox. and Environ. Safety. 54. 131-138.

DózSA-FARKAS K., 2002. Mit érdemes tudni a televényférgekröl (Enchytraeidae, Annelida)? Állattani Közlemények. 87. 149-164.

Esser, G. \& OverdiecK, D., 1991. The sublethal enchytraeid test system: Guideline and some results. In: Modern Ecology: Basic and Applied Aspects. 497-508. Elsevier. Amsterdam.

Filimonova, Z. V. \& PoKARZhevskiI, A. D., 2000. Enchytraeid (Enchytraeus crypticus) as a test organism for crude oil contamination of soil. Bull. Environ. Cont. and Tox. 65. 407-414.

HUND-RinKE, K. et al., 2002a. Bioassays for the ecotoxicological and genotoxicological assessment of contaminated soils (Results of a Round Robin Test). I. Assessment of a possible groundwater contamination: ecotoxicological and genotoxicological test with aqueous soil extracts. J. Soil and Sediments. 2. 43-50.

HuND-RINKE, K. et al., 2002b. Bioassays for the ecotoxicological and genotoxicological assessment of contaminated soils (Results of a Round Robin Test). II. Assesment of the habitat function of soils - Test with soil microflora and fauna. J. Soil and Sediments. 2. 83-90

ISO (International Organisation for Standardisation), 1998. Soil Quality - Effects of Pollutants on Earthworms (Eisenia fetida). 2. Method for the Determination of Effects on Reproduction. ISO No. 11268-2.

ISO (International Organisation for Standardisation) 1999. Soil Quality - Inhibition of Reproduction of Collembola (Folsomia candida) by Soil Pollutants. ISO No. 11267.

ISO (International Organisation for Standardisation), 2002. Soil Quality - Effects of Pollutants on Enchytraeidae (Enchytraeus sp.). Determination of Effect on Reproduction. ISO No. 16387.

ISO (International Organisation for Standardisation), 2004. Draft: Soil Quality - Avoidance Test for Evaluating the Quality of Soils and the Toxicity of Chemicals. Test with Earthworms (Eisenia fetida/andrei). Geneva, Switzerland.

IVLEVA, I. V., 1953a. Vljányie pitányija na intenszivnoszty razmnozsenyija Enchytraei. Trudi. Latv. Otdel. Vniro. 1. 197-203.

IVLEVA, I. V., 1953b. Vljanyie temperaturi i vlazsnosztyi na raszpregyelenyie Enchytraeid (Enchytraeus albidus, Henle). Trudi. Latv. Otdel. Vniro. 1. 205-212.

IVLEVA, I. V., 1953c. Roszt i razmnozsenye gorsecsnogo cservja (Enchytraeus albidus, Henle). Zool. Zsurnal Moszkau. 32. 394-404.

IVleVA, I. V., 1960. Dihanyie belogo enhitreja. Zool. Zsurnal Moszkau. 39. 165-175.

JÄNSCH, S. \& RÖMBKE, J., 2003. Ökologische Charakterisirung ausgewählter Enchytraeenarten hinsichtlich relevanter Standorteigenschaften (speziell Bodenparameter). UWSF-Zeitschrift für Umweltwissenschaften und Schadstoffkunde. 15. 95-105.

JENSEN, J. et al., 2001. Effect and risk assessment of linear alkylbenzene sulfonates in agricultural soil. 5. Probalistic risk assessment of linear alkylbenzene sulfonates in sludgeamneded soils. Environ. Tox. and Chem. 20. 1690-1697.

JuVONEN, R. et al., 2000. A battery of toxicity tests as indicators of decontamination in composting oily waste. Ecotox. and Environ. Safety. 47. 156-166.

KASPRZAK, K., 1986. Skaposzczety wodne i glebowe II. Rodzina: wazonkowce (Enchytraeidae). Warszawa.

KUPERMAN, R. G. et al., 1999. Comparison of Malathion toxicity using Enchytraeid reproduction test and earthworm toxicity test in different soil types. Pedobiologia. 43. 630-634.

Kuperman, R. G. et al., 2004. Manganese toxicity in soil for Eisenia fetida, Enchytraeus crypticus (Oligochaeta), and Folsomia candida (Collembola). Ecotox. and Environ. Safety. 57. $48-53$. 
KURT, L. A., 1961. Nyekatorie vaproszi ekologii pocsvennih maloscsetinkovih cservej cemej cemejsztve Enchytraeidae. Zool. Zsurnal Moszkau. 40. 1625-1632.

LOCK, K., 2002. Bioavailability and toxicity of metals to terrestrial organisms: Extrapolation of laboratory experiments to field situations. Dissertation. Univ. of Ghent. Ghent.

LOCK, K. \& JANSSEN, C. R., 2001a. Tolerance changes of the potworm Enchytraeus albidus after long-term exposure to cadmium. Sci. Total Environ. 280. 79-84.

LOCK, K. \& JANSSEN, C. R., 2001b. Cadmium toxicity for terrestrial invertebrates: Taking soil parameters affecting bioavailability into account. Ecotoxicology. 10. 315-322.

LOCK, K. \& JANSSEN, C. R., 2001c. Zinc and cadmium body burdens in terrestrial oligochaetes: use and significance in environmental risk assessment. Environ. Tox. and Chem. 20. 20672072.

LOCK, K. \& JANSSEN, C. R., 2002a. Multi-generation toxicity of zink, cadmium, copper and lead to the potworm Enchytraeus albidus. Environ. Poll. 117. 89-92.

LOCK, K. \& JANSSEN, C. R., 2002b. The effect of ageing on the toxicity of zinc for the potworm Enchytraeus albidus. Environ Poll. 116. 289-292.

Lock, K., De Schamphelaere, K. A. C. \& Janssen, C. R., 2002. The effect of Lindane on terrestrial invertebrates. Arch. Environ. Cont. and Tox. 42. 217-221.

Martikainen, E., 1996. Toxicity of Dimethoate to some soil animal species in different soil types. Ecotox. and Environ. Safety. 33. 128-136.

Nielsen, C. O. \& Christensen, B., 1959. The Enchytraeidae. Critical revision and taxonomy of European species (studies on nchytraeidae VII). Natura Jutlandica. 8-9. 160.

OECD (Organisation for Economic Co-operation and Development), 1984. Guideline for Testing of Chemicals No. 207. Earthworm Acute Toxicity Test. OECD. Paris.

OECD (Organisation for Economic Co-operation and Development), 2003. Guideline for Testing of Chemicals No. 220. Enchytraeidae Reproduction Test. OECD. Paris.

Posthuma L. \& Notenboom J., 2000. Toxic Effects of Heavy Metals in Three Worm Species (Eisenia fetida, Enchytraeus crypticus and enchytraeus albidus) Exposed in Artificially Contaminated Soil Substrates and Contaminated Field Soils. RIVM Report No. 719102048. Bilthoven.

Posthuma, L. et al., 1997. Single and joint toxic effects of copper and zinc on reproduction of Enchytraeus crypticus in relation to sorption of metals in soils. Ecotox. and Environ. Safety. 38. $108-121$.

RożEn, A. et al., 2004. Heavy metal concentrations in Enchytraeidae (Oligochaeta) in the Niepo omice Forest. Ecotox. and Environ. Safety. 57. 81-88.

RömBKe, J., 2003. Ecotoxicological laboratory test with enchytraeids: A review. Pedobiologia. 47. 607-616.

RömbKe, J. \& KnaCKer, T., 1989. Aquatic toxicity test for enchytraeids. Hydrobiologia. 180. $235-242$.

RömbKe, J. \& Moser, T., 1999. Organisation and Performance of an International Ringtest for the Validation of the Enchytraeid Reproduction Test. Vol. I and II. UBA-Texte 4/99.

RÖMBKE, J. \& MOSER, T., 2002. Validating the enchytraeid reproduction test: organisation and results of an international ringtest. Chemosphere. 46. 1117-1140.

Römbke, J., Notenboom, J. \& Posthuma, L., 2002. The effects of zinc on enchytraeids: The Budel case study. Natura Jutlandica. 2. 54-67.

RÖMBKE, J., RIEPERT, F. \& ACHAZI, R. K., 2000. Enchytraeen als Testorganismen. In: Toxikologische Beurteilung von Böden. 105-129. Spektrum Verlag. Heidelberg.

RömBKE, J. et al., 1994. Comparsion of effects of two pesticides on soil organisms in laboratory tests, microcosms and in the field. In: Ecotoxicology of Soil Organisms. 229-240. Lewis Publ. Chelsea, Michigan.

Salminen, J. E. \& Sulkava, P. O., 1997. Decomposer communities in contaminated soil: is altered community regulation a proper tool in ecological risk assessment of toxicants? Environ. Poll. 97. (1-2) 45-53. 
SAlminen, J. E., ERIKSSON, I. \& Haimi, J., 1996. Effects of Terbuthylazine on soil fauna and decomposition processes. Ecotox. and Environ. Safety. 34. 184-189.

SCHÄFER, R. \& ACHAZI, R. K., 1999. The toxicity of soil samples containing TNT and other ammunition derived compounds in the Enchytraeid and Collembola Biotest. Environ. Sci. and Poll. Res. 6. 213-219.

SLIMAK, K. M., 1997. Avoidance response as a sublethal effect of pesticides on Lumbricus terrestris (Oligochaeta). Soil Biol. Biochem. 29. 713-715.

Somogyi Z. et al., 2004. Mikroelem-terhelés hatása a közönséges televényféregre (Enchytraeus albidus). Agrokémia és Talajtan. 53. 155-164.

Westheide, W. \& Schmelz, R., 1997. Zur Anwendung nichtkonventioneller Methoden bei der taxonomischen Untersuchung terrestrischer Enchytraeidae (Annelida, Oligochaeta). Abhandlungen und Berichte des Naturkundmiseum Görlitz. 69. 97-113,

WEUFFEN, W., 1968. Zusammenhänge zwischen chemischer Konstitution und keimwidriger Wirkung. 20. Archiv für Experimentelle Veterinärmedizin. 22. 127-132.

WEYERS, A. et al., 2002. Statistical results and implications of the Enchytraeid Reproduction Ringtest. Environ. Sci. and Technol. 36. 2116-2121.

YeARDLEY, R. B., LAZORCHAK, J. M. \& GAST, L. C., 1996. The potential of an earthworm avoidance test for evaluation of hazardous waste sites. Environ. Toxic. and Chem. 15. 1532-1537.

Érkezett: 2005. szeptember 27.

SOMOGYI ZOLTÁN, BAKONYI GÁBOR

és KISS ISTVÁN

Szent István Egyetem, Gödöllő

Postai cím: SOMOGYI ZOLTÁN, Szent István Egyetem, MKK, Állattani- és Ökológiai Tanszék, 2103 Gödöllő, Páter Károly u. 1.E-mail: Somogyi.Zoltan@mkk.szie.hu 